УДК 811.161.2:81'371(030)

\author{
Морзе Наталія Вікторівна \\ доктор педагогічних наук, професор, член-кореспондент НАПН України, \\ проректор з інформатизації навчально-наукової та управлінської діяльності \\ Київський університет імені Бориса Грінченка, м. Київ, Україна \\ n.morze@kubg.edu.ua
}

Варченко-Троценко Лілія Олександрівна

викладач кафедри інформаційних технологій та математичних дисциплін

Київський університет імені Бориса Грінченка, м. Київ, Україна

l.varchenko@kubg.edu.ua

\title{
ФОРМУВАННЯ НАВИЧОК ЕФЕКТИВНОЇ СПІВПРАЦІ СТУДЕНТІВ ПІД ЧАС ВИКОРИСТАННЯ ВІКІ-ПОРТАЛУ
}

\begin{abstract}
Анотація. Стаття присвячена аналізу шляхів формування навичок співпраці студентів на основі використання ІКТ. Автори уточнюють поняття ефективної співпраці студентів у процесі навчанні, розглядають критерії оцінювання цієї навички 21 століття. Особливо актуальним є поняття е-співпраці студентів та різні їі форми. Однією з сучасних технологій Веб 2.0, що дозволяє ефективно організувати співпрацю студентів, $\epsilon$ Вікі-технологія. Методика використання Вікі-технології для створення відкритого освітнього середовища університету $є$ інноваційною та перспективною. Успішним прикладом організації спільної навчальної діяльності студентів на рівні навчального закладу є Вікі-портал Київського університету імені Бориса Грінченка, в рамках якого впроваджено кілька проектів різного типу та призначення.
\end{abstract}

Ключові слова: співпраця; ефективна комунікація; електронна співпраця; форми еспівпраці; сервіси Веб 2.0; Вікі-технологія; Вікі-портал; Словарь української мови; вікіпроекти.

\section{1. ВСТУП}

Сучасне інформаційне суспільство вимагає зміни парадигми освіти від знаннєвої до компетентнісної, яка б дозволила сформувати у сучасного випускника вищого навчального закладу навички 21 століття - інформаційну культуру, уміння приймати рішення й нести за них відповідальність, ефективно комунікувати, працювати в команді, креативно мислити, розв'язувати проблеми тощо. За таких умов має змінитися також роль викладача - від транслятора знань до фасилітатора, який супроводжує студентів під час навчання, мотивує їх до пізнавальної діяльності: як самостійної, так i в команді, допомагає побудувати індивідуальну траєкторію навчання на основі власних потреб i особливостей навчальної діяльності, спрямовує навчально-наукову комунікацію і співпрацю між студентами та іншими учасниками навчально-виховного процесу. Від сформованості у студентів уміння ефективно співпрацювати залежить не лише успіх навчального процесу в цілому, а й їхнє вміння бути успішними у суспільстві знань. Залишається відкритим питання методики формування й оцінювання зазначених компетентностей у студентів сучасних університетів, у яких розвивається відкрите освітнє середовище.

Аналіз актуальних досліджень. Особистісний підхід у навчанні передбачає врахування потреб і особливостей кожного студента, створення умов для підвищення їхньої внутрішньої мотивації до навчання, побудову індивідуальної траєкторії навчання 3 постійним уточнення особистісних освітніх цілей. Наразі особливого значення набувають такі технології, як гуманно-особистісні, співпраці, вільного виховання. Технології співпраці реалізують демократизм, рівність, партнерство в суб'єктних 
відносинах педагога і студента / студентів між собою, й нині потребують особливої уваги з боку педагогічної спільноти.

Питанням розвитку співпраці, співробітництва у навчанні або «колабораційного навчання» присвячено праці відомого швейцарського психолога і філософа Жана Піаже, який зазначав, що співробітництво у навчанні відіграє вагому роль у конструктивному когнітивному розвитку тих, хто навчається. Його теорія набула продовження в інших наукових працях, зокрема теорії Л. Виготського[1], що підкреслює важливість співробітництва у забезпеченні особистого розвитку. Значний внесок у сучасну педагогічну теорію спільного навчання зробив відомий український педагог А. Макаренко[2], який вважав, що у процесі соціалізації головне місце посідає вміння особи контактувати i співпрацювати 3 іншими. Питання розвитку співробітництва у навчанні на пострадянському просторі досліджував російський педагог В. Дьяченко [3]. Але найбільшого поширення співробітництво у навчанні набуло, починаючи з 90-тих років XX ст., зокрема з розвитком мережі Інтернет, особливо технологій Веб 2.0. Теоретичні і практичні засади співробітництва у навчанні розглядаються у роботах Dillenbourg [4], Smith B. та MacGregor T. [5], McManus i Aiken [6], McGuffin i Olson [7], Thomas, Funaro [8], M. Baker A. Blaye та C. O'Malley [4].

У педагогічній літературі виділяють такі стандартні види взаємодій у начальному процесі, які постійно повторюються, незалежно від особи викладача, предмета викладання, складу і характеристики навчальної групи студентів:

- - передавання відомостей викладачем - сприйняття (несприйняття) відомостей студентом;

- - організація навчальної діяльності (спільний пошук викладачем і студентами відповіді на окреслені питання плану; організація викладачем самостійної діяльності студента та ін.);

- - оцінка з боку викладача рівня підготовки студента до навчальних занять, іспитів, майбутньої професійної діяльності.

У нашому дослідженні у процесі навчальної взаємодії провідною стала не лише взаємодія між студентами і між студентами і викладачами в розумінні простої навчальної комунікації, а саме їх співпраця за допомогою інформаційнокомунікаційних технологій (ІКТ).

Метою статті $\epsilon$ аналіз шляхів формування навичок співпраці студентів у процесі навчання і визначення педагогічних умов іiі організації на основі використання технологій і сервісів Веб 2.0. Досягненню мети сприяло розв'язання низки завдань: проаналізувати різні види співпраці студентів на основі IКТ;

- розглянути приклади використання сервісів Веб 2.0 для організації співпраці студентів;

- визначити критерії оцінювання ефективної співпраці студентів у процесі навчання;

- визначити шляхи підвищення позитивної мотивації студентів до співпраці на основі використання сервісів Веб 2.0.

\section{2. РЕЗУЛЬТАТИ ДОСЛІДЖЕННЯ}

Спільна робота студентів у малих групах — це важлива складова ефективного навчання, оскільки в сучасному суспільстві значну частину свого життя людина проводить у малих групах, де розподілені ролі й визначені відповідні цілі для розв'язування різних завдань: від соціальних - у родині й суспільстві до виробничих, коли над розв'язанням складних проблем працюють колективи. Спільна робота в групі - це значно більше, ніж просто «робота разом». Головне завдання в організації 
співпраці студентів — визначення спільної мети у процесі навчання, що поділяють усі, й чітке розподілення ролей для розв'язання проблеми і завдань.

«У ситуації навчання в співпраці взаємодія визначається взаємозалежністю позитивної мети й індивідуальної відповідальності» [9].

Ефективна співпраця студентів у навчанні дозволяє їм навчатися і навчати один одного в умовах «реального» світу. «На 90-ті роки 20 століття дослідження організацій у всьому світі показали, що вміння організувати роботу в команді стало найбільш цінною характеристикою компетентності керівництва» [10].

Формування навичок співпраці є стратегічним завданням модернізації сучасного навчального процесу. Воно займає певний час і потребує спеціальних вмінь від всіх учасників навчально-виховного процесу, особливо за умов інтегрування інформаційнокомунікаційних технологій у навчальний процес.

За умов традиційного навчання студенти виконують завдання й отримують відповідні індивідуальні оцінки. Така модель навчання не забезпечує їхню повну готовність до здійснення професійної діяльності в сучасних ринкових умовах, де вони мають приймати рішення і працювати в команді для виконання завдань, які $є$ занадто складними для самостійного вирішення окремими особами. $\mathrm{y}$ сучасному взаємопов'язаному світі бізнесу з метою впровадження реальних проектів, необхідне співробітництво між компаніями і співпраця людей з різних частин світу. Цей тип діяльності вимагає навичок ефективного співробітництва, умінь продуктивно працювати в команді й інтеграції власного досвіду й ідей у єдине спільне рішення.

Організація ефективної співпраці допомагає студентам сформувати такі важливі навички, як ведення переговорів і обговорення проблем, розв'язування конфліктів, прийняття кінцевого очікуваного результату, розподіл завдань, прийняття думок та ідей інших, й інтегрування ідей в єдине ціле, відповідальність за прийняте колективне рішення, розв'язування реальних завдань. Співпраця студентів має проектуватися викладачем так, щоб їх навчальна діяльність була взаємозалежною, передбачала ситуації, коли всі студенти, виконуючи завдання в певній ролі, роблять свій внесок у досягнення командного успіху. Ефективність організації співпраці у навчанні можна оцінювати за такими ознаками:

- робота студентів, організована в парах або малих групах;

- передбачена спільна відповідальність студентів за процес навчання;

- діяльність студентів є взаємозалежною;

- передбачена необхідність прийняття студентами спільних рішень, що стосуються змісту, процесу або результату (продукту) їх спільної діяльності.

Розглянемо, як забезпечується кожна $з$ ознак ефективної співпраці студентів у процесі навчання.

Студенти будуть ефективно співпрацювати, коли їхня діяльність передбачає роботу в парах або групах, для: обговорення питання, розв'язання проблеми, створення продукту.

Водночас такі навички не формуватимуться, якщо студенти будуть виконувати свою роботу поодинці, уся група студентів не братиме участі в обговоренні проблеми, кожен студент виконуватиме своє індивідуальне завдання й відправлятиме його результати викладачеві для отримання зворотного зв'язку і відповідної оцінки.

У студентів формуються навички спільної відповідальності, якщо вони працюють у парах або групах над створенням спільного продукту, дизайну або відповіді. Спільна відповідальність більше, ніж звичайна допомога один одному: студенти мають спільно виконати роботу і мати спільну відповідальність за її результати.

Студенти приймають важливі рішення спільно, коли вони мають розв'язати важливі питання, які будуть спрямовувати їхню подальшу спільну роботу. Спільними 
вважаються рішення, які стосуються і визначають зміст, процес або результат (продукт) діяльності студентів.

- 3міст: студенти повинні використовувати свої знання для того, щоб прийняти спільне рішення, яке впливатиме на академічний зміст їхньої спільної роботи, такі як прийняття певного висновку з теми, який вони будуть писати, або прийняття гіпотези, яку вони будуть випробовувати.

- Процес: студенти мають планувати свою спільну діяльність, тобто визначати, що й коли вони будуть робити, які інструменти використовуватимуть, визначати ролі й обов'язки членів команди.

- Продукт: студенти мають внести принципові проектні рішення, які вплинуть на природу і якість спільних продуктів діяльності.

Діяльність студентів є взаємозалежною, коли всі студенти беруть участь в роботі команди для досягнення спільного успіху. Під час виконання завдання часто на групу студентів може покладатися спільна відповідальність за результат, але на практиці наразі робота не поділяється пропорційно: один чи два студенти можуть виконати завдання за всю групу, а решта — для результату просто «дописатися». Для уникнення такої ситуації необхідно структурувати навчальну діяльності так, щоб вимагати участі всіх студентів у процесі організації спільної роботи. Наприклад, під час створення спільного продукту кожний студент обов'язково готує свою частину, тоді результат їхньої спільної діяльності є взаємозалежним.

Більшість взаємозалежних результатів діяльності містить два рівні відповідальності.

- Індивідуальна відповідальність: кожен член команди відповідає за завдання, які він або вона мають виконати в межах групового завдання. Роль кожного студента в команді має важливе значення.

- Групова відповідальність: студенти мають працювати разом для отримання кінцевого продукту або результату. Студентам слід спілкуватися, обговорювати і домовитися про процес, дизайн, висновки та результати їхньої діяльності.

Важливо, щоб робота в групах була побудована так, щоб студенти планували свою діяльність разом і визначали в їхньому спільному результаті роль кожного ще на етапі планування. Наприклад, якщо кожен студент несе відповідальність за слайд презентації, а у фінальній презентації окремі слайди просто зібралися разом, це не вважається взаємозалежним результатом. Заключна презентація буде взаємозалежною, якщо студенти працюватимуть над нею разом для представлення процесу дослідження за ії використання, або обговорюватимуть основну ідею відповідного дослідження. У цьому випадку, окремі студентські слайди мають бути розроблені ними як частина єдиного цілого.

Нині інформаційно-комунікаційні технології активно використовуються в усіх галузях життя людини в сучасному суспільстві, у тому числі в освіті, і є каталізатором змін, що впливають на систему навчання, починаючи зі змісту і закінчуючи формами $\mathrm{i}$ методами навчання. Саме їх розвиток дозволив повернутися до розробки нових освітніх технологій у середній і вищій школах, що базуються на ефективній співпраці. Так, після відкриття технологій Веб 2.0 виникло поняття «е-collaboration», коли весь світ почав рухатися в напрямку обміну інформаційними даними у режимі реального часу й за допомогою інтегрованих систем обміну даним. Однак незважаючи не те, що поняття «електронна співпраця» почало використовуватися ще в кінці 1990-х років, воно залишається ще недостатньо досліджуваним [12]. Як у наукових, так і в практичних галузях існує багато різних поглядів на те, що розуміють під поняттям «електронна співпраця», і чим вона відрізняється від традиційної співпраці. В академічних визначеннях префікс «е-» в основному вказує на використання інтернет-технологій, а в 
практичних поняттях має широкий спектр визначень, які відносяться до будь-яких електронних технологій.

Отже, електронна співпраця (англ.e-collaboration) - це комплекс заходів, спрямованих на підтримку взаємодії між людьми в електронному вигляді за допомогою мережі Інтернет, які спільно працюють над розв'язанням спільних завдань. На відміну від усталеного англомовного терміну, українськомовний використовується дуже рідко.

Можна виділити три ознаки класифікації е-співпраці:

- час;

- вид зв'язку;

- кількість передавачів і приймачів.

Електронна співпраця об'єднує людей в електронному вигляді через Інтернет i використанням таких сервісів, як, наприклад, електронна пошта, соціальні мережі, блоги, вікі, спільні Інтернет-документи тощо. Це дозволяє користувачам спілкуватися i розв'язувати спільні завдання в будь-який час у будь-якому місці. Люди з різних місць навчального закладу, міста, країни чи континенту можуть обмінюватись інформаційними даними і повідомленнями, працювати над спільними електронними документами, учитися разом, приймати спільне рішення і розв'язувати проблеми, що з'являються.

До основних складових, які визначають електронну співпрацю належать:

- спільне завдання, яке можна розбити на частини;

- список ролей, які допоможуть виконати окремі частини спільного завдання;

- технології і сервіси електронної співпраці;

- особи, залучені до виконання спільного завдання;

- певні компетентності, якими володіють особи, що залучаються до співпраці;

- фізичне (матеріальне) навколишнє середовище, що оточує залучених осіб;

- соціальне навколишнє середовище.

До сервісів, функцією яких є електронна співпраця, можна зарахувати:

- телефонна конференція (також сприяє обміну відомостями, але в інтерактивній формі);

- відео- (i аудіо-) конференція - обмін відео й аудіо за допомогою комп'ютерних мереж;

- он-лайн зустріч - обмін повідомленнями в режимі реального часу;

- веб-форум - інтернет-сервіс, популярний вид спілкування в Інтернеті. На форумі створюються теми для спілкування, що робить його кращим за чат. Усі, кого цікавить певна інформація, можуть зручно й швидко переглянути іiі на форумі;

- миттєве повідомлення - мережевий сервіс для обміну текстовими повідомленнями між користувачами за допомогою комп'ютерів або інших пристроїв через комп'ютерні мережі;

- чат - мережевий сервіс для швидкого обміну текстовими повідомленнями між користувачами Інтернету в режимі реального часу;

- блог - це веб-сайт, що містить записи, зображення чи мультимедіа, які регулярно додаються;

- інтернет-портал - сайт, що надає користувачеві Інтернету різні інтерактивні сервіси, які працюють у рамках єдиного сайту;

- вікі - сайт для швидкого створення і редагування колективного гіпертексту;

- електронні списки розсилки - сервіс Інтернету, що надає можливість об'єднати певну кількість людей в єдину закриту групу розсилання;

- "біла дошка" — інтернет-сервіс для розміщення файлів, що використовуються спільно, на екрані «спільної записної книжки» або «білій дошці»; 
- група новин - це загальнодоступні дискусійний форум, як наприклад клуб за інтересами, який формують у формі каталога;

- карта розуму - сервіс для створення схем, на яких відображають слова, ідеї, завдання, або інші елементи, розташовані радіально навколо основного слова або ідеї;

- соціальна мережа - соціальна структура, утворена особами або організаціями, яка дозволяє надсилати повідомлення різного типу й відображати різні зв'язки між ними через різноманітні соціальні взаємовідносини. (табл. 1).

Порівняємо сервіси Веб 2.0, призначені для організації електронної співпраці

Таблиия 1

\section{Порівняльна таблиця сервісів, які призначені для підтримки електронної співпраці}

\begin{tabular}{|c|c|c|c|c|c|c|c|c|}
\hline Можливості користувачів & $\underset{0}{0}$ & $\frac{\bar{y}}{\underline{m}}$ & 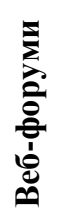 & 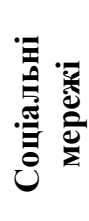 & 焉 & 量 & 竞 & 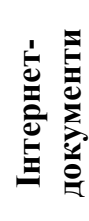 \\
\hline $\begin{array}{l}\text { Поділитися з іншими своїми } \\
\text { думками, ідеями та проектами }\end{array}$ & $\square$ & $\nabla$ & $\nabla$ & $\nabla$ & $\square$ & $\nabla$ & $\nabla$ & $\nabla$ \\
\hline $\begin{array}{l}\text { Поділитися з іншими } \\
\text { гіперпосиланнями на веб-сайти }\end{array}$ & $\nabla$ & $\square$ & $\nabla$ & $\nabla$ & $\square$ & $\nabla$ & & $\nabla$ \\
\hline $\begin{array}{l}\text { Спонукати інших до } \\
\text { висловлення своїх думок і } \\
\text { редагувати висловлювання інших }\end{array}$ & & $\square$ & & & $\nabla$ & & & $\square$ \\
\hline $\begin{array}{l}\text { Видозмінювати, доповнювати та } \\
\text { видаляти контент, створений } \\
\text { іншими }\end{array}$ & & $\nabla$ & & & $\nabla$ & & & $\square$ \\
\hline $\begin{array}{l}\text { Створювати багаторівневі } \\
\text { (багатосторінкові) веб-сайти }\end{array}$ & & $\nabla$ & & $\square$ & & & & \\
\hline $\begin{array}{l}\text { Створювати лінійні документи, у } \\
\text { яких записи розміщуються у } \\
\text { хронологічному порядку у } \\
\text { вигляді щоденника }\end{array}$ & $\nabla$ & & & $\nabla$ & & & & \\
\hline
\end{tabular}

Можна спроектувати різні сценарії організації електронної співпраці студентів на основі зазначених ознак ії ефективності. Розглянемо деякі з них.

Ефективним мережевим сервісом для організації електронної співпраці студентів може бути такий сервіс Веб 2.0, як вікі-сайт, який дозволяє студентам спільно редагувати навчальні матеріали для виконання завдання, а викладачеві побачити i проаналізувати внесок кожного з учасників у створення спільного продукту.

Вікі-сайт функціонує за спеціальною «вікі» технологією, яка дозволяє без зайвих зусиль розміщувати різноманітні освітні веб-ресурси, обмінюватись думками, повторно використовувати розміщені веб-ресурси, створювати освітні веб-ресурси на основі внеску багатьох учасників. На основі Вікі-технології створюються енциклопедії, колективні наукові проекти, соціальні мережі тощо. Головна особливість ресурсів, 
створених на iї основі, полягає в тому, що будь-яка людина може зареєструватися на ньому і написати власну статтю за певними вимогами. Інші зареєстровані на цьому ресурсі користувачі можуть іï дописувати i вносити зміни. Історія створення $\mathrm{i}$ редагування кожної так написаної статті зберігається, що дозволяє іiі авторові в будьякий час не лише переглянути всі виправлення його першоджерела, а й повернути виправлене.

У Київському університеті імені Бориса Грінченка у 2011 р. було створено Вікіпортал (wiki.kubg.edu.ua, див. рис. 1) 3 метою реалізації освітніх технологій, орієнтованих на активну спільну діяльність студентів і викладачів, усіх учасників навчально-виховного процесу.

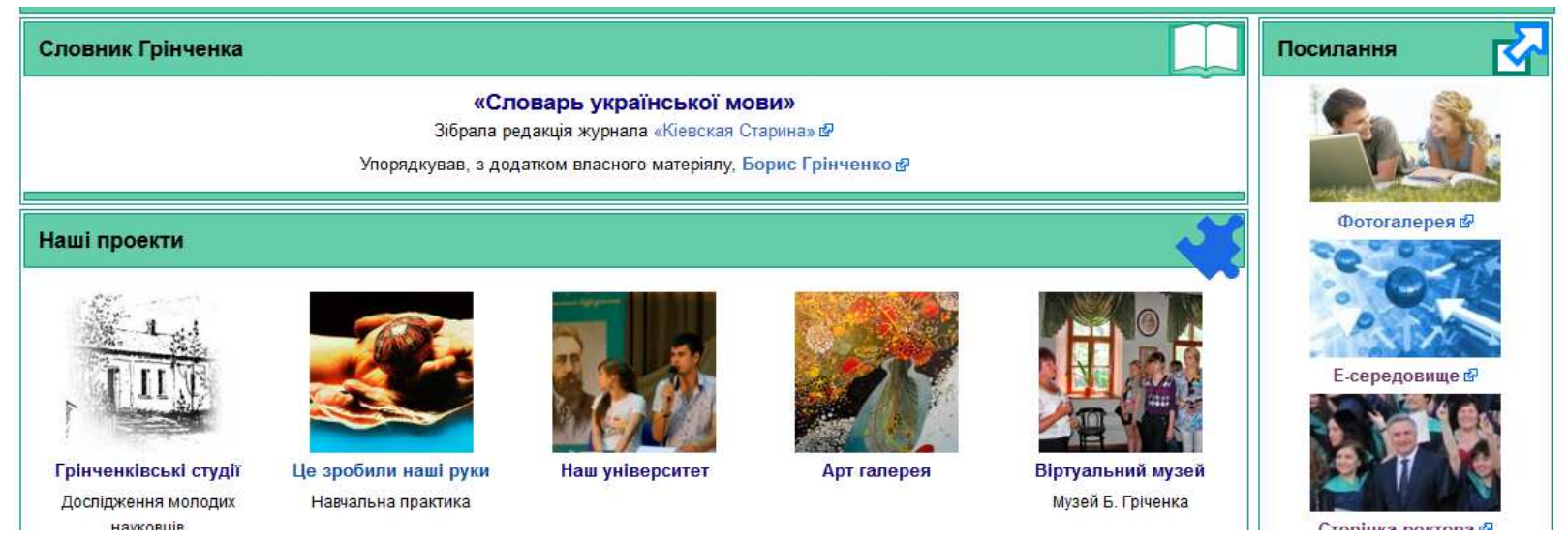

Рис. 1. Вікі-портал Київського університету імені Бориса Грінченка

Ця технологія дозволяє великій кількості користувачів наповнювати один ересурс статтями, у будь-який час самостійно і разом їх змінювати й доповнювати, обговорювати, вставляти зображення, опитування на відео, аудіо, карти знань та інші ресурси (див. рис. 2), тобто здійснювати електронну співпрацю для створення спільного ресурсу.

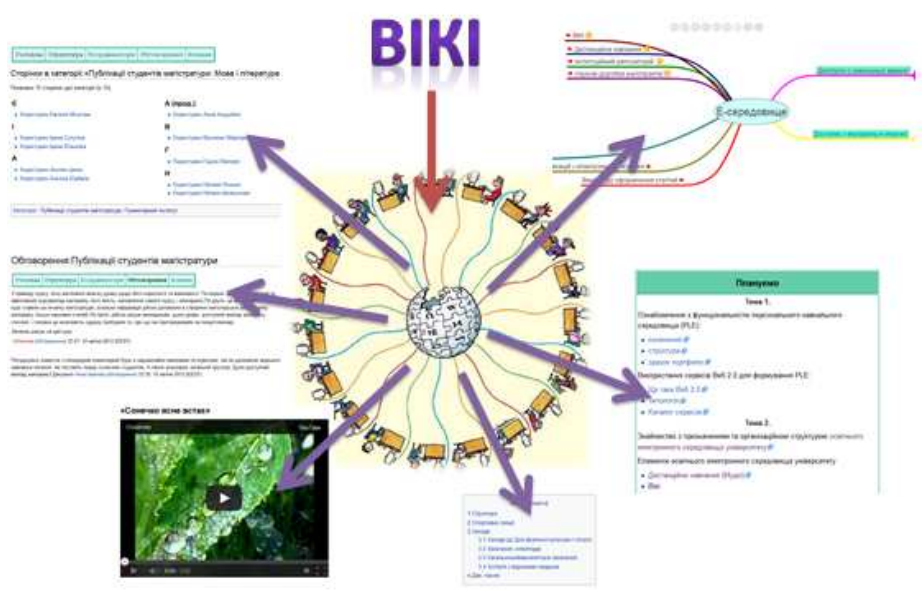

Рис. 2. Технологія «вікі»

На Вікі-порталі Університету спільними зусиллями студентів і співробітників створено проекти, які подані в табл. 2. 


\section{Проекти Вікі-порталу Київського Університету імені Бориса Грінченка}

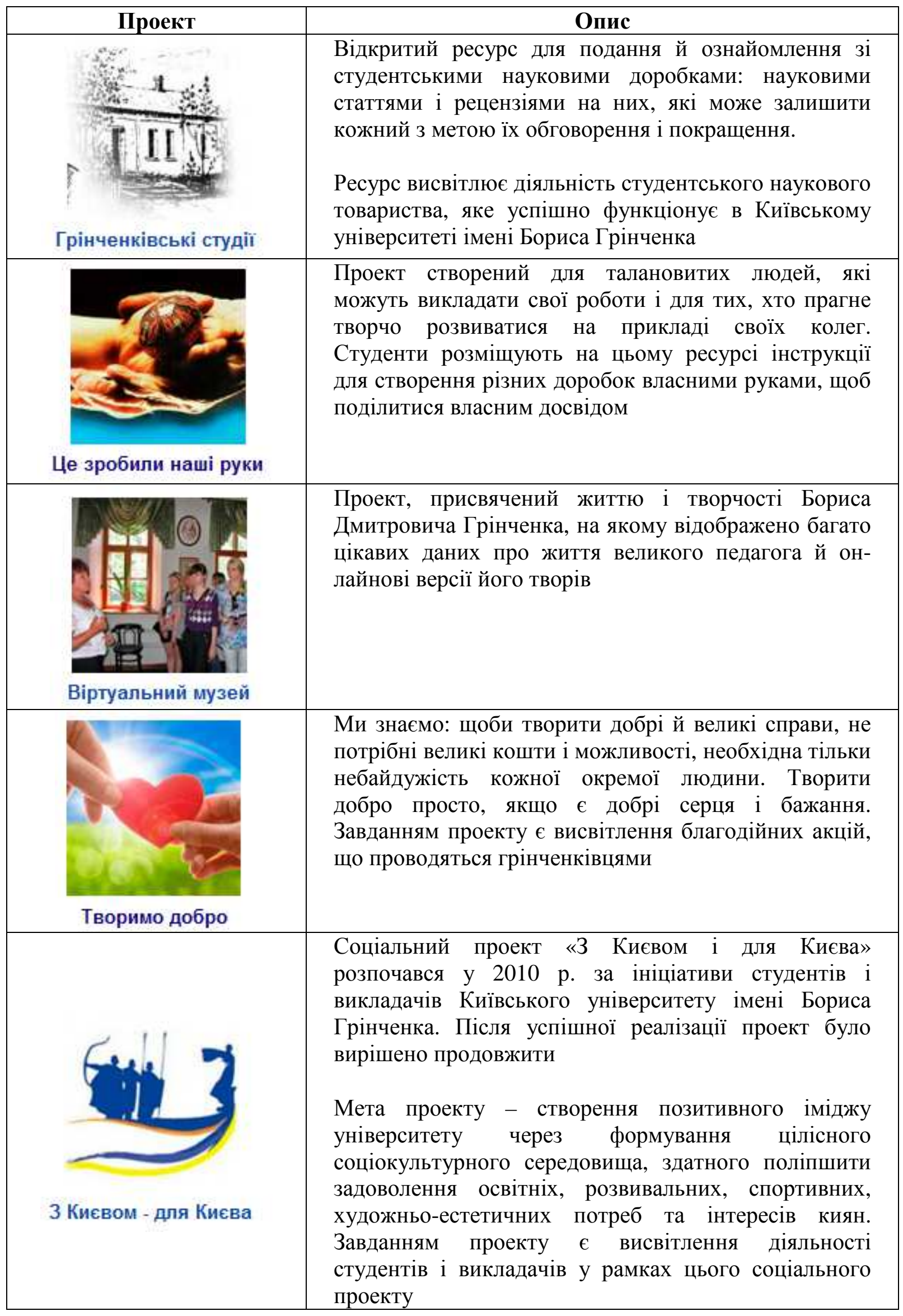




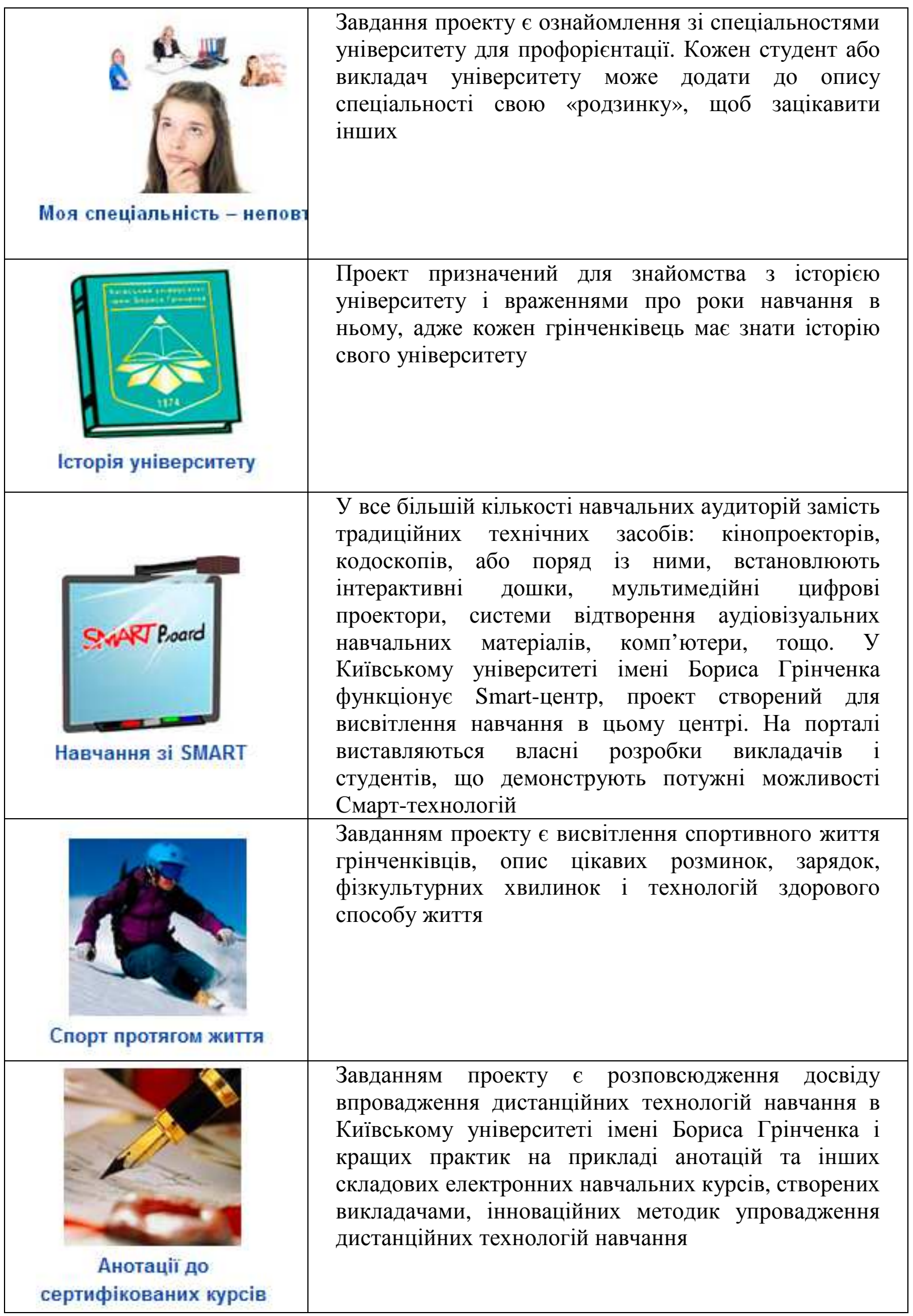


Першим колективним проектом Вікі-порталу є «Словарь української мови», до якого спочатку були додані у вигляді статей усі слова (68 тис. слів) словника Бориса Грінченка (див. рис. 3).

\section{«Словарь української мови»}

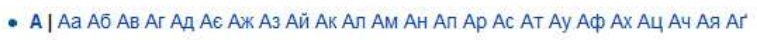

- БाБа Бг Бд Бе Бж Бз Би Бі Бл Бо Бр Бу

- в Ва Вб вд Ве Вж вз Ви Ві Вл Вн Во Вп Вр вс Вт Ву Вх Вц Вч Вш Вщц Вю Вя

- гІГаГвГдГе Ги ГіГл Гм Гн Га Го Гр Гу

- ґґа ґв ґе ґз ґи ґі ґл ґн ґо ґр ґу

- дІ Да Дб Дв Дд Де Дє Дж Дз Ди Ді ді Дл Дм Дн До Дп Др Ду Дх Дь Дю Дя

- ejег Ед Ей Екел Ем Ен Еп Ер Ес Ет Ех Еч

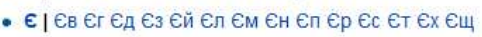

- жІжа Жб Жв Жг Жг Жд Же Жє Жи ЖІ Жл Жм Жн Жо Жр Жу

- за за зб зв зг зг зд зе зе зж зз зи зі зі зк зл зм зн зо зп зр зс зт зу зц зч зш зю зя

- иІ ив Ид Иж Ик Ил Им Ин Ир ис ит

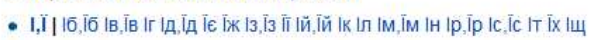

- й|йм Йн Йо Йт

- Кј Ка Кв Ке Кз Ки Кі Кл Км Кн Ко Кл Кр Кс Ку Кш

- л|Ла Ле Ли Лі Лл Ло Лу Ль Лю Ля

- м ј Ма Мr Ме Мж Ми Мі Мл Мн Мо Мр Мс Му Мч Мш Мя

- нІ На Не Ни Нi Но Ну Нь Ню Ня

- о Оа Об Ов Ог Од Ож Оз Ой Ок Ол Ом Он Оп Ор Ос От Оф Ох Оц Оч Ош Ощ Ою

- П।Па Пе Пи Пі Пї Пл Пн По Пр Пс Пт Пу Пх Пч Пш Пя

- РІ Ра Рв Рд Ре Рє Рж Ри Рі Ро Ру Рь Рю Ря

\section{Рис. 3. Проект «Словарь украӥнської мови»}

На сьогодні існують три електронні версії словника Грінченка:

1) на сайті-збірці російсько-українських словників r2u.org.ua;

2) на спеціальному сайті hrinchenko.com, створеному за перевиданням АН УРСР 1958 p.;

3) на Вікі-порталі Київського університету імені Бориса Грінченка.

Завданням проекту було долучити якомога більше студентів до ознайомлення 3 унікальним словником, створеним Борисом Грінченко, шляхом опрацювання кожного окремого слова:

- пояснення сучасного тлумачення;

- опис його в інших словниках;

- візуалізація за допомогою вставляння відповідних зображень і відео;

- пояснення через відео його тлумачення науковцями, суспільними діячами i студентами.

Студенти спочатку обирають відповідне слово зі Словника, наприклад, слово «Коваль» (див. рис. 4).

\begin{tabular}{|c|c|c|c|c|c|c|}
\hline \multirow[b]{2}{*}{ Стапт: } & & \multirow[b]{2}{*}{ Читати } & \multirow[b]{2}{*}{ Перегляд } & \multirow[b]{2}{*}{ Переглянути історію } & \multirow{2}{*}{ Пошук } & \multirow{2}{*}{ Пошук } \\
\hline & Обговорення & & & & & \\
\hline \multicolumn{7}{|c|}{ Коваль } \\
\hline \multicolumn{7}{|c|}{$\begin{array}{l}\text { Версія від 22:32, } 6 \text { вересня 2012; Matasar.ei (О6говорення • внесок) } \\
(\text { різн.) — Попередня версія • Поточна версія (різн.) • Новіша версія } \rightarrow \text { (різн.) }\end{array}$} \\
\hline \multirow{5}{*}{\multicolumn{7}{|c|}{$\begin{array}{l}\text { Коваль, -ля, м. 1) Кузнецъ. У кузні коваль, забувши про залізо в горні, балакає з хуторянами про чорну раду. К. } \\
\text { ЧР. Коваль коня кує, а жаба і собі ногу дає. Ном. № 2548. 2) Холо́дний коваль. Слесарь. Жінка старого холодного } \\
\text { коваля. Стор. МПр. 155. 3) Названіе отца новорожденнаго (на крестинахъ). Мил. 24. 4) Названіе плохого въ ходу } \\
\text { вола. КС. 1898. VII. 46. 5) Наськ.: щелкунъ, Еlater. Вх. Пч. І. 6. 6) = Коваляк. Вх. Уг. 245. 7) Наськ.: тараканъ. Вх. } \\
\text { Уг. 245. 8) Кусокъ сала, даваемый лучшему гонщику берлинъ и плотовъ. Він добре жене коваля дістане. Любечъ. } \\
\text { Ум. Ковалик, ковальчик. Ковалики в паністарій кують. Страшно. Ном. № 13650. }\end{array}$}} \\
\hline & & & & & & \\
\hline & & & & & & \\
\hline & & & & & & \\
\hline & & & & & & \\
\hline \multicolumn{7}{|c|}{ Категорія: Ко } \\
\hline
\end{tabular}

Рис. 4. Слово зі словника Бориса Грінченка 
Потім на основі спеціально створеного шаблону керівниками проекту, студенти доповнюють вікі-статтю за значеними напрямами (див. рис. 5).

\begin{tabular}{l} 
Сучасні словники \\
Тумачення слова у сучасних сповниках \\
Ілюстрації \\
Див. також \\
Джерела та література \\
Зовнішні посилання \\
\hline
\end{tabular}

Рис. 5. Шаблон для створення вікі-статті проекту

Наведемо приклад вікі-статті, створеної студентами в рамка цього проекту (рис. 6).

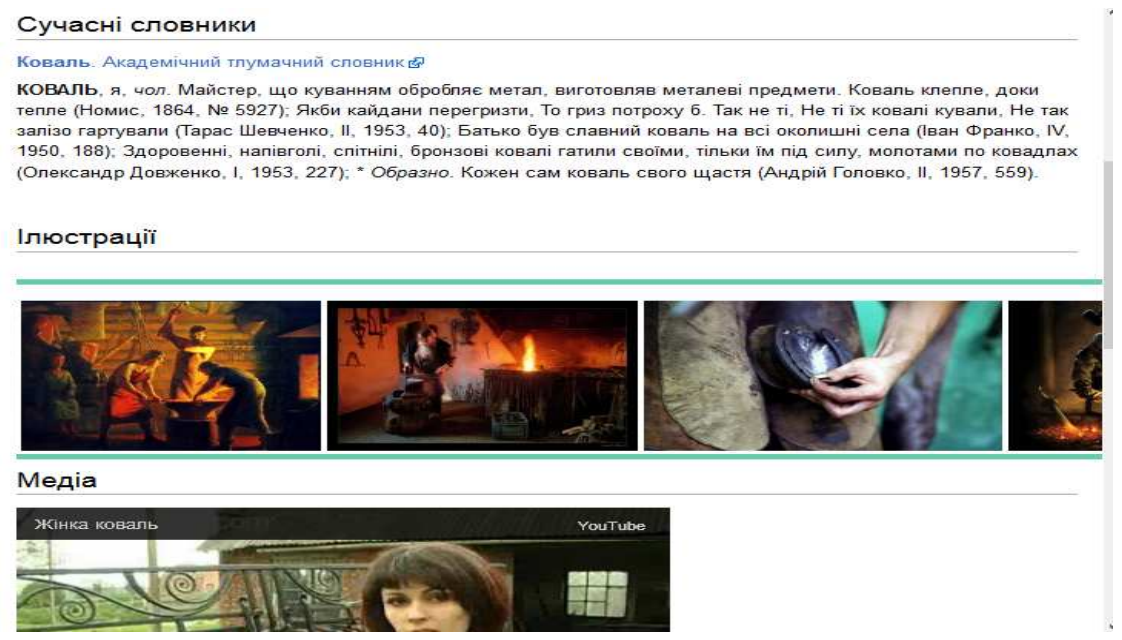

Рис. 6. Приклад подання вікі-статті для слова Словника Бориса Грінченка

Під час виконання завдань проекту студенти спільно приймають рішення щодо добору відповідного слова з метою опрацювання, типу матеріалів для відображення у статті, словників для посилання тощо. Вони вчаться приймати спільні рішення, що стосуються і визначають зміст і процес їхньої діяльності. У проекті для досягнення спільної мети беруть участь понад тисячі зареєстрованих учасників, адже одна людина не здатна за короткий час опрацювати 68 тисяч статей (саме стільки слів містить «Словарь української мови»).

Основними ідеями навчання у співпраці є спільність мети і завдань, індивідуальна відповідальність і рівні можливості успіху. Індивідуальна відповідальність означає, що успіх усієї групи залежить від внеску конкретного учасника, що передбачає допомогу, кожного члена команди один одному. Рівні можливості означають можливість кожного студента вдосконалювати свої власні досягнення. Кожен студент навчається 3 урахуванням власних можливостей і тому має шанс оцінювати себе нарівні з іншими.

Навчання у співробітництві, крім вирішення пізнавальної, творчої мети, передбачає вирішення психолого-соціальної - у процесі виконання завдання 
формується культура спілкування, оскільки передбачає всі рівні спілкування: діяльність - взаємодія - спілкування - контакт (А. А. Леонтьєва). Практично навчання у співпраці передбачає навчання в процесі спілкування (студентів між собою, 3 викладачем), у результаті якого і виникає такий необхідний контакт. У свою чергу, ефективна співпраця і спілкування може базуватися на використанні інформаційнокомунікаційних технологій.

Під час навчання у співпраці все, що представляється на загал, сприймається через призму уявлень i знань групи в цілому. Тому таке сприйняття не завжди збігається з тим, що мали на увазі студенти. У результаті створюється спільна думка 3 кожного конкретного питання. Завдання завжди виконується за обмежений час, і його виконання контролюється викладачем, зазвичай, лише на заключному етапі, коли група студентів представляє результат (продукт) своєї спільної праці.

\section{3. ВИСНОВКИ ТА ПЕРСПЕКТИВИ ПОДАЛЬШИХ ДОСЛІДЖЕНЬ}

Для формування у студентів навичок, які допоможуть їм бути успішними в сучасному суспільстві, викладач повинен змінювати форми навчання, переходити від традиційного навчання до такого, що формує у студента не лише знання, а й уміння комунікувати, працювати у команді, креативно та критично мислити. У період активного розвитку й упровадження в усі сфери життя інформаційно-комунікаційних технологій, зокрема, і в освіту, у викладача з'являється велика кількість сценаріїв організації ефективного навчально-виховного процесу.

\section{СПИСОК ВИКОРИСТАНИХ ДЖЕРЕЛ}

1. Виготський Л. С. Зібрання творів: У 6-и томах / Виготський Л. С. - М. : Педагогіка, 1984.

2. Макаренко А. (1957), Збірка творів у семи томах, 2-е вид., V.IV, с. 20, Москва.

3. Дьяченко В. (2001) «Нова дидактика». - М. : Просвіта, 2001.

4. Dillenbourg, P., Baker, M., Blaye, A. \&O'Malley, C. (1996) The evolution of research on collaborative learning. In E. Spada\& P. Reiman (Eds) Learning in Humansand Machine: Towards an interdisciplinary learning science. (Pp. 189-211). Oxford: Elsevier.

5. Smith, B. L., andMacGregor, J. T. (1992). "What is collaborative learning?" In Goodsell, A. S., Maher, M. R., andTinto, V. (Eds.), Collaborative Learning: A Sourc ebook for Higher Education. National Centeron Postsecondary Teaching, Learning, \&Assessment, Syracuse University.

6. McManus, M. M., \& Aiken, R. M. (1993). The group leader paradigmi nanintel ligent collaborative learning system. In S. Ohlsson, P. Brna, and H. Pain (Eds.), Proceeding sof the World Conference on Artificial Intelligence in Education. Charlottesville, VA: Association for the Advancemen to Computingin Education, 249-256.

7. McGuffin L. \& Olson G. M. (1992) "ShrEdit: a Shared Electronic Workspace” CSMIL Technical Report \# 45 The University of Michigan.

8. Thomas, J. W. \& Funaro, G. M. (1990), A multimedia computer-based modelfor learner-directed, collaborative problem-solving. In. Woolf, B. et. al., eds., Working Notesof 1990 Spring Symposiumserieson Knowledge-Based Environments for Learningand Teaching, 68-71, Stanford University.

9. Johnson, D. W., \&Johnson, R. T. (1998). Cooperative learning returns to college: What evidence is the rethatit works? Change, 30(4), 26-36.

10. Kagan S. Cooperative Learning. — ResourcesforTeachers, Inc., 1999.

11. Wang Y. E-Collaboration : A literature review/ Y. Wang //CUIMRC Working Paper Series. — № 036 «The Horizon Report: 2009 K-12 Edition» // New Media Consortium, 2009.

12. Бєлєнька Г. Особливості організації навчальної взаємодії викладача зі студентами 1-го курсу бакалаврату / Ганна Бєлєнька // Вісник Львівського університету. - Вип. 19. - Ч. 2. — Львів : ЛНУ, 2005. - С. 75-82. 
13. Сидоренко О. Л. Освітній простір вищого навчального закладу як визначальний чинник формування фахівця нового типу / О. Л. Сидоренко // Педагогіка і психологія. — № 3. — 2002. C. $98-100$.

14. Фіцула М. М. Педагогіка вищої школи / М. М. Фібула. - К. : Академвидав, 2006. — 356 с.

15. Пелещишин А., Пероганич Ю. Формування суспільного авторитету ВНЗ через онлайненциклопедію Вікіпедія : Матеріали 4-ї Міжнародної науково-технічної конференції CSIT-2009 «Комп'ютерні науки та інформаційні технології». — Львів : Видавництво ПП «Вежа і Ко», 2009. — C. 31-33. — http://csit2009.org - http://csit2009.org (дата звернення: 03.10.2013).

16. Michael Jonesand Lois Burgess Encouraging SME eCollaboration - The Rol of the ChampionFacilitator //Inter disciplinary Journal of E-Learning \& Learning Objects, Volume 6, 2010, 137-151. Available at : http://www.ijello.org/Volume6/IJELLOv6p137-151Jones689.pdf (дата звернення: 01.12.2013).

17. How Net Generation Students Work, available at http://people.howstuffworks.com/how-net-generationstudents-work1.htm, (дата звернення: 16.09.2013).

18. Digital Natives, Digital Immigrants By Marc Prensky, available at http://www.nnstoy.org/download/technology/Digital\%20Natives\%20-\%20Digital\%20Immigrants.pdf (дата звернення: 16.09.2013).

19. Педагогіка співпраці. URL:http://www.pedagogikafine.ru/pedagogs-958-1.html (дата звернення 03.02.2014)

20. Технології дистанційного навчання. Навчання у співпраці (collaborative learning). URL : http://dl.nw.ru/theories/technologies/content.html (дата звернення: 01.12.2013).

21. Морозов М. Н., Сморкалов А. Ю., Наумова И. А., Смирнов М. В. Теоретические основы и принципы построения информационной образовательной среды федерального университета подготовки IT-профессионалов и еепрактическая реализация // Международный электронный журнал "Образовательные технологии и общество (Educational Technology \& Society)" — 2013. — V. 16. - № 3. - $\quad$ C. 536-547. - $\quad$ ISSN 1436-4522. URL: http://ifets.ieee.org/russian/periodical/journal.html (дата звернення 03.02.2014).

22. Артеменко В. Б. Организация сотрудничества в электронном обучении на основе проектного подхода и веб-инструментов // Международный электронный журнал "Образовательные технологии и общество (Educational Technology \& Society)" — 2013. - V. 16. — № 2. — C. 536547. — ISSN 1436-4522. URL: http://ifets.ieee.org/russian/periodical/journal.html (дата звернення 03.02.2014).

23. Tapscott, Don, 2009: Grownup digital: how the netgeneration is changing your world. McGraw Hill, New York, 2009, 368 p. ISBN: 978-0-07-150863-6.

Матеріал надійшов до редакиії 01.03.2014 p.

\title{
ФОРМИРОВАНИЕ НАВЫКОВ ЕФЕКТИВНОГО СОТРУДНИЧЕСТВА СТУДЕНТОВ ПРИ ИСПОЛЬЗОВАНИИ ВИКИ-ПОРТАЛА
}

\author{
Морзе Наталия Викторовна \\ профессор, член-корреспондент НАПН Украины, \\ проректор по информатизации учебно-научной и управленческой деятельности \\ Киевский университет имени Бориса Гринченко, г. Киев, Украина \\ n.morze@kubg.edu.ua
}

Варченко-Троценко Лилия Александровна

преподаватель кафедры информационных технологий и математических дисциплин

Киевский университетимени Бориса Гринченко, г. Киев, Украина

l.varchenko@kubg.edu.ua

Аннотация. Статья посвящена анализу путей формирования навыков сотрудничества студентов при использовании ИКТ. Авторы уточняют понятие эффективного сотрудничества студентов при обучении и критерии оценивания. Особенно актуальным является понятие э-сотрудничества студентов и разные его формы. К одной из современных технологий Веб2.0, применение которой позволяет эффективно организовать сотрудничество студентов, относится Вики-технология, методика использования которой является инновационной и перспективной. Методика использования Вики во время создания открытого учебного пространства университета является инновационной и 
перспективной. Успешным примером организации совместной учебной деятельности студентов на уровне учебного заведения является Вики-портал Киевского университета имени Бориса Гринченко.

Ключевые слова: сотрудничество; эффективная коммуникация; электронное сотрудничество; формы э-сотрудничества; сервисы Веб2.0; Вики-портал; «Словарь української мови»; вики-проекты.

\title{
FORMATION OF STUDENTS' EFFECTIVE COOPERATION SKILLS BASING ON USAGE OF WIKI-PORTAL
}

\author{
Nataliia V. Morze \\ doctor of pedagogic science, professor, corresponding member NAPS of Ukraine, \\ Vice-Rector for Informatization of Teaching, Scientific and Managing Activity \\ Borys Grinchenko Kyiv University, Kyiv, Ukraine \\ n.morze@kubg.edu.ua
}

Liliia O. Varchenko-Trotsenko

IT teacherand mathematics disciplines chair Borys Grinchenko Kyiv University, Kyiv, Ukraine l.varchenko@kubg.edu.ua

\begin{abstract}
The article is devoted to the analysis of the formation ways of the students' cooperation skills basing on the usage of ICT. Authors clarify the conception of collaboration of the students. Particularly actual is the conception of students' e-collaboration. To one of the modern Web 2.0 technologies, application of which lets organize efficiently the students collaboration, is related the Wiki, which methodic of usage is innovative and perspective. Methods of using Wiki in creating open educational environment of the University is an innovative and promising. The successful example of the organization of students' common educational activity is the Wiki-portal of Borys Grinchenko Kyiv University, in frames of which have been realized several projects of different type and purpose.
\end{abstract}

Keywords: collaboration; effective communication; e-collaboration; forms of e-collaboration; services Web-2.0; Wiki-portal; Dictionary of Ukrainian language; wiki-projects.

\section{REFERENCES (TRANSLATED AND TRANSLITERATED)}

1. Vygotsky L.S., Collected Works: in 6 volumes / L.S.Vygotsky Moscow: Pedagogy, 1984. (in Ukrainian)

2. Makarenko, A. (1957), a collection of works in seven volumes, 2nd ed.,V.IV., p. 20., Moscow. (in Ukrainian)

3. Dyachenko V. (2001) "New didactics". — M.: Education. 2001. (in Ukrainian)

4. Dillenbourg, P., Baker, M., Blaye, A. \&O'Malley, C.(1996) The evolution of research on collaborative learning. In E. Spada\& P. Reiman (Eds) Learning in Humans and Machine: Towards an interdisciplinary learning science. (Pp. 189-211). Oxford: Elsevier. (in English)

5. Smith, B. L., and MacGregor, J. T. (1992). "What is collaborative learning?" In Goodsell, A. S., Maher, M. R., and Tinto, V. (Eds.), Collaborative Learning: A Source book for Higher Education. National Centeron Postsecondary Teaching, Learning, \& Assessment, Syracuse University. (in English)

6. McManus, M.M., \&Aiken, R.M. (1993). The group leader paradigm in an intelligent collaborative learning system. In S. Ohlsson, P. Brna, and H. Pain (Eds.), Proceedings of the World Conferenceon Artificial Intelligence in Education. Charlottesville, VA: Association for the Advancement of Computingin Education, 249-256. (in English)

7. McGuffin L. \&Olson G.M. (1992) "ShrEdit: a Shared Electronic Workspace" CSMIL Technical Report \# 45 The University of Michigan. (in English)

8. Thomas, J.W. \& Funaro, G.M. (1990), A multimedia computer-based model for learner-directed, collaborative problem-solving. In. Woolf, B. et. al., eds., Working Notes of 1990 Spring Symposium series on Knowledge-Based Environments for Learning and Teaching, 68-71, Stanford University. (in English) 
9. Johnson, D. W., \&Johnson, R. T. (1998). Cooperative learning returns to college: What evidence is the rethatit works? Change, 30(4), 26-36. (in English)

10. Kagan S. Cooperative Learning. - Resources for Teachers, Inc. - 1999. (in English)

11. Wang Y. E-Collaboration : A literaturereview/ Y.Wang //CUIMRC WorkingPaper Series. — №036 «TheHorizonReport: 2009 K-12 Edition» // NewMediaConsortium. - 2009. (in English)

12. Belenka G. Peculiarities of the organization of educational interaction of the teacher with the students of the 1st year of the bachelor / GannaBelenka // Lviv University bulletin. - Issue. 19. — P.2. - Lviv: LNU, 2005. - P. 75-82. (in Ukrainian)

13. Sidorenko O.L. Informative space of higher educational establishment as determinative factor in formation of the specialist of the new type. / O.L. Sidorenko // Pedagogic and Psychology . — № 3. 2002. - P. 98-100. (in Ukrainian)

14. Fitsula M.M. Pedagogic of the higher school / M.M. Fitsula. — K.:Academvudav, 2006. - 356 c. (in Ukrainian)

15. Peleschyshyn A.,Peroganich Y. Forming of the society authority of HEE through the Wikipedia onlinecollection: Materials of the 4th International science-technical conference CSIT-2009 «Computer sciences and informational technologies» [online]. — Lviv: PP «Vezha and Co» publishers, 2009, — p. 31-33. - Available from: http://csit2009.org (accessed on 03.10.2013). (in Ukrainian)

16. Michael Jonesand LoisBurgessEncouraging SME eCollaboration - The Roleofthe Champion Facilitator [online] // Interdisciplinary Journalof E-Learning \& Learning Objects, Volume 6, 2010, 137-151. — Available from:http://www.ijello.org/Volume6/IJELLOv6p137-151Jones689.pdf (accessed on 01.12.2013). (in English)

17. How Net GenerationStudentsWork [online]. — Available from: http://people.howstuffworks.com/hownet-generation-students-work1.htm, (accessed on 16.09.2013). (in English)

18. Digital Natives, Digital Immigrants By Marc Prensky [online]. - Available from: http://www.nnstoy.org/download/technology/Digital\%20Natives\%20-\%20Digital\%20Immigrants.pdf, (accessed on 16.09.2013). (in English)

19. Pedagogy collaboration.[online]. - Available from: http://www.pedagogikafine.ru/pedagogs-958-1.html (accessed on 03.02.2014) (in Ukrainian)

20. Technologies Distance Learning. Collaborative learning. [online]. — Available from: http://dl.nw.ru/theories/technologies/content.html (accessed on 01.12.2013). (in Ukrainian)

21. Morozov M.N., Smorkalov A., Naumova A. Smirnov MV Theoretical bases and principles of information educational environment Federal University training IT-professionals and its practical implementation [online] // International Journal of Electronic "Educational Technology \& Society". — 2013. — V.16. №3. - - C.536-547. - $\quad$ - ISSN $\quad$ 1436-4522. - Available from: http://ifets.ieee.org/russian/periodical/journal.html (accessed on 03.02.2014). (in Russian)

22. Artemenko V.B., Organization for Cooperation in e-learning based on the project approach and web tools [online] // International Journal of Electronic " Educational Technology \& Society". — 2013. — V.16. - №2. - - C.536-547. - ISSN 1436-4522. — Available from: http://ifets.ieee.org/russian/periodical/journal.html (accessed on 03.02.2014). (in Russian)

23. Tapscott, Don, 2009: Grownup digital: how the net generation is changing your world. McGraw Hill, NewYork, 2009, 368p. ISBN: 978-0-07-150863-6. (in English) 